\title{
Perinatal stress: Characteristics and effects on adult eating behavior
}

\author{
Estresse peri-natal: suas características e \\ repercussões sobre o comportamento \\ alimentar na vida adulta
}

Matilde Cesiana da SILVA ${ }^{1}$

Ligia Cristina Monteiro GALINDO²

Julliet Araújo de SOUZA ${ }^{3}$

Raul Manhães de CASTRO $^{2}$

Sandra Lopes de SOUZA ${ }^{4}$

\begin{abstract}
A B S T R A C T
Many studies have pointed out the importance of mother-child interaction in the early months of life. A few decades ago, a method called kangaroo care was developed and its main goal was to keep underweight or premature newborns in direct contact with the mother. This method has reduced the morbidity and mortality of these newborns, increasing their growth rate, breastfeeding time and mother-child contact. In rodents, the dam's presence is crucial for avoiding aggression factors that may trigger phenotypic adaptations in the pups with irreversible morphological, functional and behavioral consequences. Eating behavior is an adaptive response stemming from the external environment demand and modulated by opportunities and limitations imposed by the external environment. This behavior is regulated by a complex interaction of peripheral and central mechanisms that control hunger and satiety. The hypothalamus is a brain structure that integrates central and peripheral signals to regulate energy homeostasis and body weight. The hypothalamic nucleus have orexigenic peptides, such as neuropeptide $Y$ and the Agouti-related peptide, and anorexigenic peptides, such as cocaine and amphetamine regulated transcript and proopiomelanocortin. An innovative study of eating behavior in experimental models of neonatal stress separates the mother from the offspring during lactation. This review describes the effects of stress during the neonatal period on general physiological factors, particularly on the control of eating behavior.
\end{abstract}

Indexing terms: Feeding behavior. Perinatal. Rats. Stress.

1 Universidade Federal de Pernambuco, Centro Acadêmico de Vitória, Núcleo de Nutrição. Vitória de Santo Antão, PE, Brasil.

2 Universidade Federal de Pernambuco, Centro de Ciências Biológicas, Departamento de Anatomia. Av. Prof. Moraes Rego, s/n., Cidade Universitária, 50670-901, Recife, PE, Brasil. Correspondência para/Correspondence to: LCM GALINDO. E-mail: <sanlopesufpe@gmail.com>.

3 Universidade Federal de Pernambuco, Centro de Ciências da Saúde, Programa de Pós-Graduação em Nutrição. Recife, PE, Brasil.

${ }^{4}$ Universidade Federal de Pernambuco, Centro de Ciências da Saúde, Departamento de Nutrição. Recife, PE, Brasil. 


\section{RE S U M O}

Muitos estudos têm apontado a importância da interação mãe-filho durante os primeiros meses de vida. Nas últimas décadas, foi desenvolvido um método, denominado mãe canguru, que tem como principal objetivo manter neonatos nascidos com baixo peso ou prematuros em contato direto com suas mães de forma contínua. Esse método tem reduzido a mortalidade e morbidade desses neonatos, aumentado medidas de crescimento, amamentação e contato mãe-filho. Em roedores, a presença da mãe é determinante para evitar a incidência de fatores agressores que possam desencadear adaptações fenotípicas dos filhotes com consequências morfofuncionais e comportamentais irreversíveis. O comportamento alimentar representa uma resposta adaptativa, decorrente da demanda do ambiente interno sendo modulado por oportunidades e limitações impostas pelo ambiente externo. Esse comportamento é regulado por uma interação complexa entre mecanismos periféricos e centrais que controlam a fome e a saciedade. O hipotálamo é a estrutura encefálica que integra sinais centrais e periféricos para regular a homeostase energética e o peso corporal. Nos núcleos hipotalâmicos são encontrados peptídeos orexigênicos como o neuropeptídeo Y e o peptídeo relacionado ao gene Agouti, e os anorexigênicos como o transcrito relacionado a cocaína e anfetamina e a pró-opiomelanocortina. O estudo do comportamento alimentar é inovador em modelos experimentais de estresse neonatal utilizando a separação entre mães e filhotes na fase de lactação. Esta revisão descreve os efeitos do estresse durante o período neonatal sobre aspectos fisiológicos gerais e particularmente sobre o controle do comportamento alimentar.

Termos de indexação: Comportamento alimentar. Perinatal. Ratos. Estresse.

\section{NTRODUCTION}

Many studies have pointed out the importance of the mother-child interaction during the first months of life for proper infant growth'. Especially in cases of prematurity, this contact has proven effective against morphological and functional impairments in these newborns ${ }^{2}$. Hence, a few decades ago a method called kangaroo care was developed. Its main objective is to keep low birth weight or premature newborns in direct contact with their mothers ${ }^{2}$. This method has reduced the morbidity and mortality of these newborns, increasing their growth rate, breastfeeding time and the motherchild contact ${ }^{3}$. The morphological and functional adaptations to different durations and conditions of mother-child contact are known from studies with rodents influenced by contact. The presence of the dam is essential for avoiding the incidence of aggression factors that may trigger phenotypic adaptations in the pups with irreversible morphological, functional and behavioral consequences ${ }^{3}$. This characteristic is explored in experimental models of neonatal stress that separate the mother from the offspring during lactation ${ }^{4}$. Periodic maternal separation may cause malnutrition, thermal stress and damages to the somatosensory contact ${ }^{5}$. One of the most common models involves repeated separation of the mother from the offspring (maternal separation model) and also of the offspring from the mother (maternal deprivation model) during lactation. These offspring show greater neuroendocrine responsiveness to stress in adulthood ${ }^{6}$, and greater vulnerability to depression, anxiety and eating disorders ${ }^{7}$, among others.

The objective of this review is to point out the repercussions of neonatal stress on the control mechanisms of eating behavior. Food intake and metabolism compose the two sides of the energy balance of an organism. Today, a high percentage of the global population has accumulated energy in the form of adipose tissue, which is considered a positive energy balance status, clinically defined as obesity. The great prevalence of obesity today is associated with genetic factors and with events that may have happened in early life. There are numerous accounts of eating and metabolic disorders in individuals who have been exposed to adverse environments in early life ${ }^{8}$. As an example, there are studies that show an important relationship between anorexia and bulimia nervosa in youth and sexual abuse during childhood. In animal studies, poor nutrition during 
gestation and lactation promotes polyphagia and accumulation of body fat during adulthood. Studies of animal models of neonatal stress (maternal separation) found that in adulthood, these animals develop a preference for palatable foods, considered obesogenic. The identification of the damaging effects of maternal separation by experimental studies on eating behavior provides a base for clinical studies, helping to prevent eating disorders.

\section{S TRE S S}

The word stress was used for the first time in 1936 by the Hungarian physician Hans Selve in the publication "What is stress?". Known as general adaptation syndrome, stress is an unspecific response of the body to any external demand ${ }^{9}$. This response is divided into 3 stages: alarm (identification of the stressing agent), resistance (successfully fight off the stressing agent) and exhaustion (caused by harmful stress effects, the body can no longer respond to the stressing agent). The stressing agent is described as something that disrupts the body's homeostasis and thereby requires a physiological response ${ }^{8}$.

There are two classical stress response systems described in the literature: a) The neurovegetative system characterized by the release of adrenaline by the adrenal medulla; and b) The neuroendocrine system characterized by the release of glucocorticoids produced in the adrenal cortex in response to hypothalamic and hypophyseal stimuli. The acute activation of these systems is adaptive, promoting greater energy availability and blood to target organs. However, prolonged exposure to glucocorticoids stemming from the chronic activation of this system may be harmful ${ }^{9}$.

Any physical disturbance elicits a response to the stressing agent to maintain homeostasis and ease adaptation. In mammals, this response is triggered by the Hypothalamic-Pituitary-Adrenal Axis (HPA). The typical neuroendocrine response to stress takes seconds: a) Increased secretion of catecholamines (adrenaline and noradrenaline) by the sympathetic nervous system; b) Activation of the Paraventricular Nucleus (PVN) of hypothalamus for expression of ArginineVasopressin (AVP) and Corticotropin-Releasing Hormone (CRH); and c) Increased Oxytocin (Oxt) secretion by the posterior pituitary. PVN neurons project to the medium eminence, allowing the release of peptides from the hypophyseal portal system ${ }^{10}$. This results in the synthesis and release of many peptides with a common precursor, Proopiomelanocortin (POMC). Endogenous opioids, such as $\beta$-endorphin and Adrenocorticotropic Hormone (ACTH) are among these peptides ${ }^{11}$. The HPA system that involves the release of glucocorticoid hormones by the adrenal gland (cortisol in humans and corticosterone in rats) is slow and persistent ${ }^{11}$. A few minutes after an individual has been exposed to a stressing agent, plasma glucocorticoid levels increase, peaking between 30 and 60 minutes after the initial exposure. The $\mathrm{CRH}$ system is the initial factor in the neurochemical, behavioral and endocrine response to stress ${ }^{12}$. The HPA axis, when stimulated by stress, activates $\mathrm{CRH}$ in the hypothalamus, promoting the release of $\mathrm{ACTH}$ by the anterior pituitary, which tells the adrenal gland to release glucocorticoids, such as corticosterone in rodents and cortisol in humans. Corticosterone has a negative feedback effect on the pituitary gland and hypothalamus, that is, it inhibits the release of $\mathrm{ACTH}$ and $\mathrm{CRH}^{12}$. The glucocorticoid hormones are the final effectors of the HPA axis. These hormones promote homeostasis by mobilizing energy reserves, and catabolizing proteins, glycogen and fat. Furthermore, they improve cognitive function and inhibit the secretion of sex steroids. A sudden rise of glucocorticoid levels triggers a salutary adaptive response; however, high levels for long periods may harm the nervous system and other tissues and are associated with ventricular dilatation, cerebral atrophy, low cognitive capacity and possible neurotoxicity ${ }^{13}$. Corticosterone effects are mediated by two receptor subtypes: mineralo- 
corticoid and glucocorticoid, with greater and smaller affinity for corticosterone, respectively ${ }^{13}$.

Mineralocorticoid receptors participate in the control of basal excitability and behavioral responsiveness, while glucocorticoid receptors are involved in terminating the stress response. These receptors may also act as ligand-dependent transcription factors. Mineralocorticoid receptors are found in some limbic areas, such as the hippocampus, while glucocorticoids are found in many brain regions, including the frontal cortex and $\mathrm{PVN}^{13}$. Glucocorticoid receptors have a key regulating role in the neuroendocrine control of the HPA axis and in the termination of the stress response. This occurs because it has a negative feedback effect on receptors of the hypothalamus and hypophysis, and in structures of the limbic system, such as the hippocampus and amygdala. Negative feedback operates in two modes: proactive, which involves the maintenance of baseline levels of the HPA axis, and reactive mode, which suppresses stress-induced $\mathrm{ACTH}$ and Corticosterone (CORT) levels ${ }^{13}$. The first mode determines sensitivity of the stress response or its threshold and involves functions of mineralocorticoid receptors with high affinity for corticosterone located in the higher brain regions. The second involves low-affinity glucocorticoid receptors located in PVN neurons, corticotropes, which are abundant in the cortical regions, hippocampus and ascending aminergic pathways, where they mediate the modulatory influence of corticosterone on HPA activity. The activation of mineralocorticoid receptors in the hippocampus inhibits activity of the HPA axis ${ }^{14}$. Hippocampal efferent projections activate GABAergic neurons located in the ventral lateral septum and Bed Nucleus of the Stria Terminalis (BNST), which project to neurons in the parvocellular region of the $\mathrm{PVN}^{14}$. The inhibition promoted by these hormones limits their action, which prevents catabolic, anti-reproductive and immunosuppressive effects on the body ${ }^{14}$.

The greater incidence of depression and other disorders in women is related to their greater vulnerability to stress. The nervous system has gender-related specificities in the anatomic, metabolic and neurochemical levels, and in the responses to emotional stimuli. Clinical studies have found that the HPA axis has a function of sexual dysmorphism in normal or pathological conditions. Females have a greater baseline level of stress-induced cortisol and are more resistant to dexamethasone suppression of the HPA axis ${ }^{15}$.

Many studies with rats have found sexrelated differences in HPA-axis function and in their responses to stressing situations or anxiety. These differences include greater responsiveness of the HPA axis, with stress-induced high plasma levels of the hormones ACTH and corticosterone in females. The amount of corticosterone secreted by females is not constant, it varies along the estral cycle $^{16}$. Studies in humans suggest that steroid hormones are the main culprits in the genderrelated differences associated with the HPA axis. Estrogen hinders the negative feedback of glucocorticoids, which enhances the stress response. It has been suggested that the greater sensitivity of the female HPA axis is related to estrogen-induced $\mathrm{CRH}$ transcription via receptors located in the PVN. However, note that genderrelated differences in stress response are not limited to the HPA axis and circulating hormones, they are also found in the central neurotransmission systems ${ }^{17}$.

Events that occur during the rapid development of the nervous system, gestation and lactation in rats, and up to the third year of life in humans, are some of the factors that may change the body's response to stress. The periodic separation of dam and pups has been used as a model of perinatal stress. In adulthood, rats submitted to maternal separation demonstrate high anxiety, learning and memory deficits, high CRH expression in the PVN and hippocampus, and low glucocorticoid binding capacity to hippocampal receptors. Additionally, maternal separation modulates adult neurogenesis in the hippocampus ${ }^{18}$. 


\section{Stress during the neonatal period}

During neonatal rodent development, there is a period of low responsiveness to stress (Stess Hyporesponsive period - SHRP), where the response of the adrenal gland to stress is minimum or inexistent. The main characteristics of this period are the high negative feedback effect of glucocorticoids on the hypothalamus and hypophysis, low adrenal sensitivity to $\mathrm{ACTH}$ and minimum corticosterone increase in response to most stressors. During the first two weeks after birth, the levels of corticosterone, ACTH and $\mathrm{CRH}$ in rodents are low ${ }^{16}$. This stage of HPA hyporesponsiveness may be an adaptive and protective mechanism, since high corticosterone levels during this critical period has harmful and catabolic effects, which include inhibition of brain growth, neuronal division, dendrite development and neuronal metabolism.

In the rat's brain, glucocorticoid receptors are functional by the $13^{\text {th }}$ embryonic day, and the negative feedback of the HPA axis by corticosterone is established between the 13th and $17^{\text {th }}$ days. In the early neonatal period, changes in the blood levels of corticosterone may affect the amount of these receptors ${ }^{19}$. The plasma levels of ACTH and corticosterone are high on the first day of life but they drop significantly from the second day on, and remain low during the first two weeks of life. The levels of these hormones will match those of adults on day 21, that is, around weaning time ${ }^{19}$. The immaturity of the adrenal gland of the developing rat is a consequence of the low synthesis and/or secretion of $\mathrm{CRH}$ and ACTH by the hypophysis during the first weeks of life. During the first two weeks of the rat's life, saturation of the pituitary glucocorticoid receptors may be associated with the highly inhibited ACTH release ${ }^{20}$. During SHRP, free corticosterone circulation is high and may have access to tissues, especially corticotropic tissues, which may contribute to the high sensitivity of the feedback system during this period $^{21}$. Moreover, glucoreceptors may act at the suprahypophysial level to inhibit the synthesis and/ or secretion of $\mathrm{CRH}$ and AVP. Low levels of circulating glucocorticoids during the first two weeks of life seem to be essential for normal brain development. Glucocorticoids are important for normal brain maturation since they initiate terminal maturation, remodel axons and dendrites and impact cell survival. High glucocorticoid levels impair the development and function of the nervous system ${ }^{22}$. The administration of glucocorticoids in pregnant rats delays neuronal maturation and myelination, changing neuronal structure, synapse formation and neurogenesis ${ }^{23}$.

Despite the existence of SHRP, many studies have shown neurochemical and behavioral changes that may persist throughout life when an individual is exposed to stressors during this period. Although hyporesponsive, these individuals have an acute response to the stress promoted by maternal separation, even when they are not exposed to any other stressor ${ }^{24}$. During this phase, transcortin levels (a protein that transports glucocorticoids) are low and most glucocorticoids circulate in the plasma in an unbound state, that is, in a biologically active state $^{25}$. Therefore, despite the low total plasma concentration of glucocorticoids during SHRP, the concentration of their active form is high, which suffices for their biological actions. This must also be the mechanism responsible for the role played by stress in the programming of the nervous system and behavioral expression. In rats, at the end of the second week of life, the HPA axis matures, and there is a gradual increase in the baseline levels of corticosterone and stress responsiveness ${ }^{26}$. There is a close relationship between HPA axis development, the environment and the establishment of adult behavioral patterns ${ }^{26}$.

In rats, repeated maternal separation during the lactation period (neonatal stress model) promotes adulthood anxiety, learning and memory deficits ${ }^{27}$, high expression of $\mathrm{CRH}$ in the PVN of the hypothalamus and hippocampus, and fewer glucocorticoid receptors ${ }^{28}$. Variations in the care provided by dams to nursing pups affect gene regulation, neuronal number, neurotransmitter levels, and neuroendocrine and behavioral functions in response to stress. High dam care is 
associated with low reactivity to stress in adult life, including low anxiety, HPA tonus and stress responsiveness ${ }^{29}$. In humans, passive and active tactile stimulation of premature infants improve behavioral development, visceral function and maturation of the sympathetic and adrenal systems ${ }^{30}$.

\section{Neonatal stress and eating behavior}

Eating behavior is an adaptive response stemming from the demand of the internal environment, modulated by opportunities and limitations imposed by the external environment. This behavior is regulated by a complex interaction between peripheral and central mechanisms that control hunger and satiety ${ }^{31}$. The hypothalamus is the brain structure that integrates central and peripheral signals to regulate energy homeostasis and body weight ${ }^{32}$. The hypothalamic nuclei contain orexigenic peptides, such as Neuropeptide Y (NPY) and Agouti-related Peptide (AgRP), and anorexigenic peptides, such as Cocaine and Amphetamine Regulated Transcript (CART) and Proopiomelanocortin (POMC) ${ }^{33}$. Many peripheral substances act on the neurons that produce these peptides to influence eating behavior ${ }^{33}$. Among these are the hormones involved in the stress response.

Stress promotes important adjustments to energy metabolism. Individuals exposed to stressful situations have low food intake and body weight and high energy expenditure ${ }^{34}$. However, when food is energy-dense or palatable, stress promotes high intake ${ }^{35}$. When submitted to a test of food preferences, stressed individuals prefer fatty foods ${ }^{36}$. Glucocorticoids may be responsible for the preference for palatable foods. The removal of glucocorticoids by adrenalectomy reduces food intake by $10 \%$ to $20 \%$, slowing weight gain ${ }^{37}$.

Neonatal stress adjusts eating behavior in response to different demands during adulthood, since HPA axis dysfunction is related to the pathogeneses of eating disorders ${ }^{38}$. Rats that were separated from their dams are more vulnerable to the development of anorexia nervosa. Individuals with eating disorders are usually survivors of childhood abuse, and HPA dysfunction is implicated in this pathophysiology ${ }^{39}$. Many patients with eating disorders report being childhood-abuse survivors. A study with patients with bulimia nervosa found that many of their parents were separated, divorced or widowed ${ }^{40}$. Another study reported that patients with bulimia nervosa were more likely to have been sexually abused during childhood than patients with anorexia nervosa ${ }^{40}$.

Not many studies of experimental models of neonatal stress describe its repercussions on the mechanisms that control eating behavior. In rats, food intake during adulthood was not affected by maternal separation. However, when these animals were submitted to food restriction cycles, they presented rebound polyphagia ${ }^{41}$. Being separated from the dam promoted high food intake in adolescent rats that were exposed to successive cycles of food restriction and abundance, possibly because of the increased responsiveness of the HPA axis. Rats are considered adolescents at 60 days of age, when they reach sexual maturity ${ }^{42}$.

Glucocorticoids are involved in the regulation of energy balance and affects hypothalamic neuropeptides ${ }^{43}$. Neurons that express NPY in the hypothalamic arcuate nucleus have glucocorticoid receptors. High plasma levels of corticosterone may be necessary for increasing the expression of messenger Ribonucleic Acid (mRNA) NPY44.

Animals that survived perinatal malnutrition, a type of stress, have polyphagia associated with high levels of hypothalamic peptides that stimulate hunger (NPY) and low levels of those that inhibit it $(\mathrm{POMC})^{45}$, as well as changes in the serotonergic control of satiety ${ }^{46}$. On the one hand, maternal separation increases the baseline levels of hypothalamic NPY47; on the other, it inhibits this increase in response to fasting ${ }^{48}$. The baseline levels of anorexigenic hypothalamic peptides, such as POMC and CART, and orexigenic peptides, such as NPY, are not changed by maternal separation 
of young female rats ${ }^{49}$. However, when these female rats are submitted to a 48-hour fast, maternal separation affected the expression of these neuropeptides, with an increase in NPY and reduction in POMC and CART ${ }^{50}$. This review indicates that different factors involved in the mother-child interaction have distinct programming influences on adult eating behavior.

\section{CONTRIBUTORS}

MC SILVA database search and article writing; SL SOUZA article writing and review; LCM GALINDO, RM CASTRO and JA SOUZA final article review.

\section{REFERENCES}

1. Conde-Agudelo A, Belizán JM, Diaz-Rossello J. Kangaroo mother care to reduce morbidity and mortality in low birthweight infants (Review). Cochrane. 2011; (3):1-115.

2. Caldji C, Diorio J, Meaney MJ. Variations in maternal care in infancy regulate the development of stress reactivity. Biol Psychiatry. 2000; 48(12):1164-74.

3. Ruedi-Bettschen D, Feldon J, Pryce CR. Circadianand temperature-specific effects of early deprivation on rat maternal care and pup development: shortterm markers for long-term effects? Dev Psychobiol. 2004; 45(2):59-71.

4. Hofer MA, Brunelli SA, Shair HN. Potentiation of isolation-induced vocalization by brief exposure of rat pups to maternal cues. Dev Psychobiol. 1994; 27(8):503-17.

5. Orozco-Solis R, Matos RJ, Lopes de Souza S, Grit I, Kaeffer B, Manhaes de Castro R, et al. Perinatal nutrient restriction induces long-lasting alterations in the circadian expression pattern of genes regulating food intake and energy metabolism. Int J Obes. 2011; 35(7):990-1000.

6. Liu D, Diorio J, Day JC, Francis DD, Meaney MJ. Maternal care, hippocampal synaptogenesis and cognitive development in rats. Nat Neurosci. 2000; 3(8):799-806.

7. Ladd CO, Huot RL, Thrivikraman KV, Nemeroff CB, Meaney MJ, Plotsky PM. Long-term behavioral and neuroendocrine adaptations to adverse early experience. Prog Brain Res. 2000; 122:81-103.

8. El Khoury A, Gruber SH, Mork A, Mathe AA. Adult life behavioral consequences of early maternal separation are alleviated by escitalopram treatment in a rat model of depression. Prog Neuropsychopharmacol Biol Psychiatry. 2006; 30(3): 535-40.
9. Selye H. A syndrome produced by diverse nocuous agents: 1936. J Neuropsychiatry Clin Neurosci. 1998; 10(2):230-1.

10. Pacak K, Palkovits M, Yadid G, Kvetnansky R, Kopin IJ, Goldstein DS. Heterogeneous neurochemical responses to different stressors: A test of Selye's doctrine of nonspecificity. Am J Physiol. 1998; 275(4 Pt 2):R1247-55.

11. Kopin IJ. Definitions of stress and sympathetic neuronal responses. Ann N Y Acad Sci. 1995; 771:19-30.

12. McEwen BS. The neurobiology and neuroendocrinology of stress: Implications for post-traumatic stress disorder from a basic science perspective. Psychiatr Clin North Am. 2002; 25(2): 469-94.

13. Tsigos C, Chrousos GP. Hypothalamic-pituitaryadrenal axis, neuroendocrine factors and stress. J Psychosom Res. 2002; 53(4):865-71.

14. Dallman MF, Akana SF, Strack AM, Scribner KS, Pecoraro N, La Fleur SE, et al. Chronic stress-induced effects of corticosterone on brain: Direct and indirect. Ann N Y Acad Sci. 2004; 1018:141-50.

15. O'Callaghan JP, Miller DB. Spinal glia and chronic pain. Metabolism. 2010; 59 (Suppl 1):S21-6.

16. Johnson JD, O'Connor KA, Deak T, Spencer RL, Watkins LR, Maier SF. Prior stressor exposure primes the HPA axis. Psychoneuroendocrinology. 2002; 27(3):353-65.

17. De Kloet ER, Vreugdenhil E, Oitzl MS, Joels M. Brain corticosteroid receptor balance in health and disease. Endocr Rev. 1998; 19(3):269-301.

18. Sapolsky RM, Romero LM, Munck AU. How do glucocorticoids influence stress responses? Integrating permissive, suppressive, stimulatory, and preparative actions. Endocrine Rev. 2000; 21(1):55-89.

19. Plotsky PM, Meaney MJ. Early, postnatal experience alters hypothalamic corticotropin-releasing factor ( $\mathrm{CRH}$ ) mRNA, median eminence $\mathrm{CRH}$ content and stress-induced release in adult rats. Brain Res Mol Brain Res. 1993; 18(3):195-200.

20. Habib KE, Gold PW, Chrousos GP. Neuroendocrinology of stress. Endocrinol Metab Clin North Am. 2001; 30(3):695-728.

21. Van de Kar LD, Blair ML. Forebrain pathways mediating stress-induced hormone secretion. Front Neuroendocrinol. 1999; 20(1):1-48.

22. Phillips GB. Endogenous sex hormones and type 2 diabetes risk. Jama. 2006; 296(2):168-9.

23. Meijer OC, de Kloet ER. Corticosterone and serotonergic neurotransmission in the hippocampus: Functional implications of central corticosteroid receptor diversity. Crit Rev Neurobiol. 1998; 12(1-2):1-20.

24. Meijer OC, Kortekaas R, Oitzl MS, de Kloet ER. Acute rise in corticosterone facilitates $5-\mathrm{HT}(1 \mathrm{~A})$ 
receptor-mediated behavioural responses. Eur J Pharmacol. 1998; 351(1):7-14.

25. Tritos N, Kitraki E, Philippidis H, Stylianopoulou F. Neurotransmitter modulation of glucocorticoid receptor mRNA levels in the rat hippocampus. Neuroendocrinology. 1999; 69(5):324-30.

26. Evans RM, Arriza JL. A molecular framework for the actions of glucocorticoid hormones in the nervous system. Neuron. 1989; 2(2):1105-12.

27. Gesing A, Bilang-Bleuel A, Droste SK, Linthorst AC, Holsboer F, Reul JM. Psychological stress increases hippocampal mineralocorticoid receptor levels: Involvement of corticotropin-releasing hormone. J Neurosci. 2001; 21(13):4822-9.

28. Jacobson L, Sapolsky R. The role of the hippocampus in feedback regulation of the hypothalamicpituitary-adrenocortical axis. Endocrine Rev. 1991; 12(2):118-34.

29. de Kloet ER, Reul JM, de Ronde FS, Bloemers M, Ratka A. Function and plasticity of brain corticosteroid receptor systems: action of neuropeptides. J Steroid Biochem. 1986; 25(5B):723-31.

30. de Kloet ER. Steroids, stability and stress. Front Neuroendocrinol. 1995; 16(4):416-25.

31. Meaney MJ, Diorio J, Francis D, Widdowson J, LaPlante P, Caldji C, et al. Early environmental regulation of forebrain glucocorticoid receptor gene expression: Implications for adrenocortical responses to stress. Dev Neurosci. 1996; 18(1-2):49-72.

32. Reul JM, Sutanto W, van Eekelen JA, Rothuizen J, de Kloet ER. Central action of adrenal steroids during stress and adaptation. Adv Exp Med Biol. 1990; 274:243-56.

33. van Oers HJ, de Kloet ER, Whelan T, Levine S. Maternal deprivation effect on the infant's neural stress markers is reversed by tactile stimulation and feeding but not by suppressing corticosterone. J Neurosci. 1998; 18(23):10171-9.

34. Herman JP, Prewitt CM, Cullinan WE. Neuronal circuit regulation of the hypothalamo-pituitaryadrenocortical stress axis. Crit Rev Neurobiol. 1996; 10(3-4):371-94.

35. Curtis AL, Bethea T, Valentino RJ. Sexually dimorphic responses of the brain norepinephrine system to stress and corticotropin-releasing factor. Neuropsychopharmacology. 2006; 31(3):544-54.

36. Duchesne A, Dufresne MM, Sullivan RM. Sex differences in corticolimbic dopamine and serotonin systems in the rat and the effect of postnatal handling. Prog Neuropsychopharmacol Biol Psychiatry. 2009; 33(2):251-61.

37. Young EA. Sex differences and the HPA axis: Implications for psychiatric disease. J Gend Specif Med. 1998; 1(1):21-7.

38. Klein LC, Corwin EJ. Seeing the unexpected: How sex differences in stress responses may provide a new perspective on the manifestation of psychiatric disorders. Curr Psychiatry Rep. 2002; 4(6):441-8.

39. Kudielka BM, Kirschbaum C. Sex differences in HPA axis responses to stress: A review. Biol Psychol. 2005; 69(1):113-32.

40. Blanchard RJ, McKittrick CR, Blanchard DC. Animal models of social stress: Effects on behavior and brain neurochemical systems. Physiol Behav. 2001; 73(3):261-71.

41. Karandrea D, Kittas C, Kitraki E. Contribution of sex and cellular context in the regulation of brain corticosteroid receptors following restraint stress. Neuroendocrinology. 2000; 71(6):343-53.

42. Karandrea D, Kittas C, Kitraki E. Forced swimming differentially affects male and female brain corticosteroid receptors. Neuroendocrinology. 2002; 75(4):217-26.

43. Beiko J, Lander R, Hampson E, Boon F, Cain DP. Contribution of sex differences in the acute stress response to sex differences in water maze performance in the rat. Behav Brain Res. 2004; 151(1-2):239-53.

44. Seale JV, Wood SA, Atkinson HC, Harbuz MS, Lightman SL. Gonadal steroid replacement reverses gonadectomy-induced changes in the corticosterone pulse profile and stress-induced hypothalamicpituitary-adrenal axis activity of male and female rats. J Neuroendocrinol. 2004; 16(12):989-98.

45. Johnston $A L$, File SE. Sex differences in animal tests of anxiety. Physiol Behav. 1991; 49(2):245-50.

46. Mendelson SD, McEwen BS. Autoradiographic analyses of the effects of restraint-induced stress on 5-HT1A, 5-HT1C and 5-HT2 receptors in the dorsal hippocampus of male and female rats. Neuroendocrinology. 1991; 54(5):454-61.

47. Viau V, Meaney MJ. Variations in the hypothalamicpituitary-adrenal response to stress during the estrous cycle in the rat. Endocrinology. 1991; 129(5):2503-11.

48. Imhof JT, Coelho ZM, Schmitt ML, Morato GS, Carobrez AP. Influence of gender and age on performance of rats in the elevated plus maze apparatus. Behav Brain Res. 1993; 56(2):177-80.

49. Burgess LH, Handa RJ. Chronic estrogen-induced alterations in adrenocorticotropin and corticosterone secretion, and glucocorticoid receptor-mediated functions in female rats. Endocrinology. 1992; 131(3):1261-9.

50. Lunga P, Herbert J. 17 Beta-oestradiol modulates glucocorticoid, neural and behavioural adaptations to repeated restraint stress in female rats. J Neuroendocrinol. 2004; 16(9):776-85.

Received on: 7/3/2012

Final version on: 6/6/2012 Approved on: 27/2/2013 